\title{
Editorial
}

\section{What are the responsibilities of Public Health Nutritionists in the context of war?}

Recently I was sent an email with a link to a petition put together by staff and graduate students of Cornell University. The email was headed 'Nutrition and Public Health Scientists against War'. It invited colleagues throughout the world to sign the petition and send it on. When I last checked there were 1261 signatures, which include mine and no doubt those of many readers of this journal. Below is an extract from the petition:

While the public is aware of the many Iraqi and American lives that will be lost during the war, these numbers will be dwarfed by the lives damaged and lost in the humanitarian crisis that will follow the war. Because of the vulnerability of children to malnutrition and infectious disease, Iraqi children will constitute the majority of those who will die in the aftermath of war.

The problem of civilian suffering will be enormous. According to a recent UN report, (http://www.casi.org. uk/info/undocs/war021210scanned.pdf) as many as 500,000 Iraqis could require medical treatment as a result of serious injuries suffered in the early stages of a war on Iraq. The report also "estimated that the nutritional status of some 3.03 million persons countrywide will be dire and that they will require therapeutic feeding." More than 2 million children will become malnourished. As a result of a war inflicted by the United States an estimated 2 million people will require some assistance with shelter.

As far as I know this is the first time that our profession has collectively spoken out about the impact of war on public health nutrition. Perhaps we should have done so before. I believe the most important benefit of living in a democracy is that of responsible free speech. Is it not our responsibility to speak out, as citizens, and then as scientists? I believe the case for the invasion of Iraq has not been made, and so that the war on Iraq is unjust. I also believe I have both a moral and a professional responsibility to say so, because to remain silent is to condone the war and to ignore its devastation of Iraqi public health.

The Cornell petition has made me reflect on my experience as a teacher in public health nutrition and what issues motivate students to action. Judging from my experience we teachers have failed to mobilise our students on the issue of malnutrition, but our students have been mobilised on the issue of the invasion of Iraq. I believe they are right as citizens, and also as young public health nutrition professionals, because of the effect the war will have on the nutritional status of the children of Iraq. Our students can teach us about commitment and the meaning of our work, and we have something to teach them about the underlying and basic causes of malnutrition.

The big picture stuff is often a struggle - because we are trained to focus on detail - and inevitably it will often feel as though global power politics is beyond us. But public health is all about the big picture, doing what is best to prevent and control epidemics and to promote population health. And when we are sure what causes epidemics, and what impedes their prevention and control, our duty is to speak, and act. Thus, how can spending billions to 'free' the Iraqi people be justified, while at the same time money is not found to free hundreds of millions of children from poverty and early death? Think how many children could be empowered to take control of their lives by being taught to read, with the money now spent on bombs, not just in Iraq but around the world every day! Virtually all families could have access to safe and clean water for a fraction of the cost of the US military machine. And after the fighting in Iraq has ceased I wonder how much money will be available for sustained humanitarian support, compared with the vast cost of waging a war which most people believe is wrong?

Over the last six months I have been lucky enough to attend two programmes originated by Jo Hautvast and his colleagues, and now led by Frans Kok and Clive West, entitled the European (and African) Nutrition Leadership programmes. These are aimed at fostering leadership among young nutrition scientists for the future. At the African programme, held in October, it was very moving to see that white Afrikaner men and black African women could listen to each other, and see that under the skin were people with the same commitments and interests and concerns. A different world felt possible. We public health nutrition teachers can and should give our time to encourage such new beginnings. Maybe future leaders of our profession will do better than we have done, in helping to create a world in which there is steadily increasing equity and tolerance. 
Public health nutrition is about policy: a fact recognised by the founders of the Nutrition Society. Over half a century later we should decide what now is the place of our profession in public life. What do you think? Should we engage passionately, or simply let our work speak for us? Should we stay away from politics? I will welcome contributions from readers on the issue of the responsibilities of public health nutritionists in the context of the attack on Iraq.

Barrie Margetts

Editor-in-Chief 